\title{
Diabetes mellitus type 2: factors related to adherence to self-care
}

\author{
Diabetes mellitus tipo 2: fatores relacionados com a adesão ao autocuidado \\ Diabetes mellitus tipo 2: factores relacionados a la adhesión al autocuidado
}

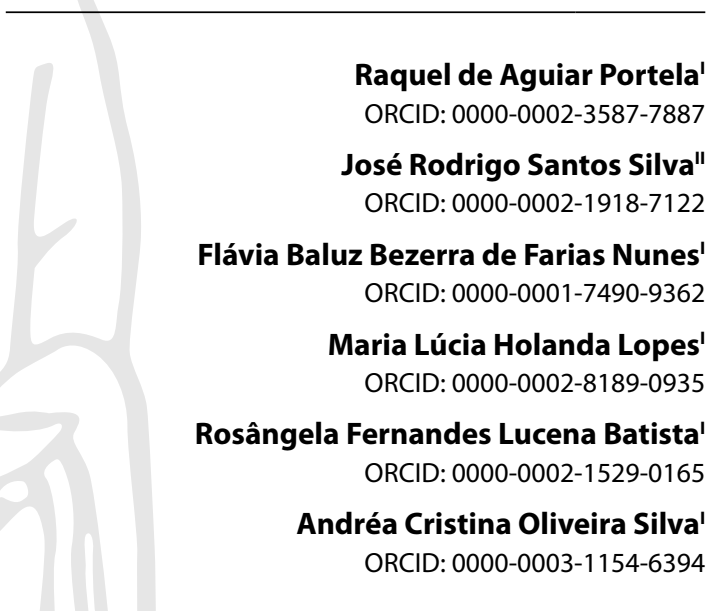

'Universidade Federal do Maranhão. São Luís, Maranhão, Brazil. "Universidade Federal de Sergipe. Aracaju, Sergipe, Brazil.

How to cite this article: Portela RA, Silva JRS, Nunes FBBF, Lopes MLH, Batista RFL, Silva ACO. Diabetes mellitus type 2 . factors related to adherence to self-care. Rev Bras Enferm. 2022;75(4):e20210260. https://doi.org/10.1590/0034-7167-2021-0260

Corresponding author:

Raquel de Aguiar Portela

E-mail: raquelportela23@hotmail.com

EDITOR IN CHIEF: Álvaro Sousa ASSOCIATE EDITOR: Hugo Fernandes

Submission: $05-26-2021$

Approval: 11-04-2021

\section{ABSTRACT}

Objectives: to analyze the sociodemographic and clinical variables related to the adherence to self-care activities in people with diabetes mellitus type 2 . Methods: quantitative, crosssectional study, carried out with 270 people with diabetes from December 2019 to October 2020, in São Luís, Maranhão. Results: the adherence to self-care was greater when it comes to medications $\left(M_{d}=7.0\right)$ and foot care $\left(M_{d}=6.0\right)$, but lower in regard to blood sugar testing $\left(M_{d}=1.0\right)$, exercise $\left(M_{d}=2,0\right)$, and diet (general) $\left(M_{d}=4.0\right)$. The variables age group $(p=0.007)$ educational level $(p=0.015)$, body mass index $(p=0.035)$, complications with diabetes $(p=0.009)$, and nutritional follow-up $(p=0.000)$ had associations with self-care activities. Conclusions: identifying the factors related to the adherence to self-care was found to be essential to strengthen the line of care in chronic diseases and to direct educational actions, aiming to improve the quality of life of people with diabetes.

Descriptors: Type 2 Diabetes Mellitus; Self Care; Behavior; Nursing Care; Treatment Adherence and Compliance.

\section{RESUMO}

Objetivos: analisar as variáveis sociodemográficas e clínicas relacionadas com a adesão às atividades de autocuidado em pessoas com diabetes mellitus tipo 2. Métodos: estudo quantitativo, transversal, realizado com 270 pessoas com diabetes, entre dezembro de 2019 e outubro de 2020, em São Luís, Maranhão. Resultados: houve adesão mais favorável ao autocuidado quanto ao uso do medicamento $\left(M_{d}=7,0\right)$ e cuidados com os pés $\left(M_{d}=\right.$ $6,0)$ e adesão menos desejável quanto à monitorização da glicemia $\left(M_{d}=1,0\right)$, prática da atividade física $\left(M_{d}=2,0\right)$ e alimentação geral $\left(M_{d}=4,0\right)$. As variáveis faixa etária $(p=0,007)$, escolaridade $(p=0,015)$, índice de massa corporal $(p=0,035)$, complicação do diabetes $(p=0,009)$ e acompanhamento nutricional $(p=0,000)$ apresentaram associação com as atividades de autocuidado. Conclusões: a identificação dos fatores relacionados com a adesão ao autocuidado mostrou-se essencial para o fortalecimento da linha de cuidados em doenças crônicas e direcionamento das ações educativas, visando melhorar a qualidade de vida das pessoas com diabetes.

Descritores: Diabetes Mellitus Tipo 2; Autocuidado; Comportamento; Cuidados de Enfermagem; Cooperação e Adesão ao Tratamento.

\section{RESUMEN}

Objetivos: analizar variables sociodemográficas y clínicas relacionadas a la adhesión a actividades de autocuidado en personas con diabetes mellitus tipo 2. Métodos: estudio cuantitativo, transversal, realizado con 270 personas con diabetes, entre diciembre de 2019 y octubre de 2020, en São Luís, Maranhão. Resultados: hubo adhesión más favorable al autocuidado cuanto al uso del medicamento $\left(M_{d}=7,0\right)$ y cuidados con los pies $\left(M_{d}=\right.$ $6,0)$ y adhesión menos deseable cuanto al monitoreo de la glucemia $\left(M_{d}=1,0\right)$, práctica de actividad física $\left(M_{d}=2,0\right)$ y alimentación general $\left(M_{d}=4,0\right)$. Las variables franja etaria $(p=0,007)$, escolaridad $(p=0,015)$, índice de masa corporal $(p=0,035)$, complicación del diabetes $(p=0,009)$ y acompañamiento nutricional $(p=0,000)$ presentaron relación con las actividades de autocuidado. Conclusiones: la identificación de factores relacionados a la adhesión al autocuidado se mostró esencial para el fortalecimiento de la línea de cuidados en enfermedades crónicas y direccionamiento de acciones educativas, visando mejorar la calidad de vida de personas con diabetes.

Descriptores: Diabetes Mellitus Tipo 2; Autocuidado; Conducta; Atención de Enfermería; Cumplimiento y Adherencia al Tratamiento. 


\section{INTRODUCTION}

The diabetes mellitus (DM) and its complications are the main cause of early death in several countries, with more than 4 million deaths of people from 20 to 79 years old in 2019. It is an important global challenge because it affects the health of individuals, families, as well as that of society and health systems, due to the impact it has on the quality of life of people as it leads to disabilities, lowers productivity, and provokes chronic complications due to the disease $\mathrm{e}^{(1-2)}$.

However, diabetes complications are less common and less severe in people who control their glycemia well. Many people with the disease can prevent or delay the emergence of serious consequences to their health by carrying out the correct treatment and following recommendations of changes in their lifestyle $\mathrm{e}^{(2)}$.

For effective changes in the lifestyle and an effective management of the disease, it becomes necessary to develop self-care activities that include the adherence to healthy diets, the practice of physical activities, the monitoring of one's glycemia, care for one's feet, correct use of drugs, and quitting smoking. All of these contribute for proper DM management ${ }^{(3)}$.

It should be highlighted that these activities are the responsibility of the individual, of their relatives, and of the health professionals and institutions. In this context, the health professionals should identify difficulties and potential, aiming to encourage the autonomy of the person, and recognizing their main role in health care by valuing individual aspects to define goals and priorities, leading to a joint creation of a plan for care and for monitoring the results. As such, they can motivate the adherence of people with DM to self-care activities ${ }^{(4)}$.

Studies have indicated a low adherence to good self-care practices, which reflects on an increase of complications connected to the disease ${ }^{(5)}$, in addition to the few number of researches about the factors associated to physical activity ${ }^{(6)}$ (an indispensable practice for the control of diabetes), we recognized the importance of researching in depth this topic based on the variables related to adherence to self-care. Therefore, one seeks to contribute for the implementation of educational guidance, having a positive impact on the quality of life of people with diabetes.

Considering the above, it becomes clear how necessary it is to analyze the sociodemographic and clinical variables related to the adherence to self-care activities in people with diabetes mellitus type 2 (DM2), so health workers can direct their assistance, establishing strategies to help people with diabetes better understand their disease and the importance of daily care and treatment - aspects that directly impact the progress of the disease.

\section{OBJECTIVES}

To analyze the sociodemographic and clinical variables related to the adherence to self-care activities in people with diabetes mellitus type 2 .

\section{METHODS}

\section{Ethical aspects}

This project was approved by the Research Ethics Committee according to Research Ethics Committee from the National Council of Health ${ }^{(7)}$.

\section{Design, period, and place of study}

Cross-sectional and quantitative study, guided by the instrument STROBE. Data collection took place from December 2019 to October 2020 in the central district of the city of São Luís, state of Maranhão (MA), Brazil. It occurred in health units that attend people with DM2 or through domiciliary visits mediated by the community health agents from the Family Health Strategy (ESF) teams of the city.

\section{Population or sample; criteria of inclusion and exclusion}

The population of the study was formed by 671 people with DM2, registered in the health units of the district Centro. To define the size of the sample, the formula to calculate finite populations was used. Since these studies do not use estimates of proportion or general mean of the adherence to self-care activities, we considered a proportion of $50 \%$ of the population, the number of people with DM2 registered in the health units $(n=671)$, an estimated $5 \%$ error, and a confidence level of $95 \%$, with a $10 \%$ increase in the sample to compensate for potential losses or exclusions. This led to a sample of 270 people with DM2.

The sample was non-probabilistic, by convenience, and to select these people with diabetes and form the sample, the following inclusion criteria were adopted: being older than 18 years old, being part of the ESF teams of the health units from the district Centro of the city of São Luís (MA), and being diagnosed with DM2 for, at least, six months, an amount of time found to be sufficient for the patient to go through some changes in their routines due to the diagnosis of the disease. The exclusion criterion was the presence of problems that could prevent or impair verbal communication. These were verified by checking whether the patient could state their age or date of birth, the day of the week, and the day of the month.

\section{Study protocol}

For data collection, the Form of Sociodemographic and Clinical Data, created by the researcher, was applied at first. It contemplates information about sex, age, educational level, family income, participation in an education group in diabetes, Body Mass Index (BMI), time of diagnosis, drugs prescribed to treat the diabetes, complications caused by diabetes, in addition to nutritional, medical, and nursing follow ups.

Then, the Summary of Diabetes Self-Care Activities Questionnaire (SDSCA) was used, in a version translated and culturally adapted for Brazil, named Questionário de Atividades de Autocuidado como Diabetes (QAD). This is considered to be a reliable and valid instrument to evaluate the adherence to self-care of people with DM2. It has 6 dimensions and 15 items to evaluate diabetes self-care: diet (general), with two items; diet (specific), three items; exercise, two items; blood sugar testing, two items; foot care, three items; and medications (according with the regimen established), three items ${ }^{(8)}$.

The answers are related to the adherence to the activities of self-care for diabetes in the last seven days. For an analysis of the adherence, the items of the questionnaire could be answered with a number from 0 to 7 days, where 0 is the least desirable and 7 the most. Therefore, to maintain this standardization in the interpretation of the results, the items of the dimension diet (specific), which asks about the intake of fat-rich foods and sweets, 
had their values inverted $(7=0 ; 6=1 ; 5=2 ; 4=3 ; 3=4 ; 2=5 ; 1=$ $6 ; 0=7$ and vice-versa), as recommended by the revised SDSCA. A mean value of adherence is generated for each item of self-care Therefore, adherence to the activities of self-care was considered to be satisfactory when the mean number of days was five or more ${ }^{(9)}$.

\section{Analysis of results and statistics}

A descriptive analysis of data was carried out, with the record of frequency and percentages of qualitative variables. Regarding the adherence to the QAD scores, the normal distribution was evaluated using Shapiro-Wilk's test MannWhitney's and Kruskal-Wallis's nonparametric hypothesis tests were used, since none of the scores being studied had a normal distribution. The results were presenting as medians, interquartile ranges (IQR) and $p$-values, with a significance level of 5\%. The analysis used the R software, version 4.0.0.

\section{RESULTS}

From the 270 people interviewed, $69.6 \%$ were female, $39.3 \%$ were in from 60 to 69 years of age, $47.0 \%$ were married/in a stable union, and $57.8 \%$ had elementary education. $50.4 \%$ were retired and $80.4 \%$ received from 1 to 2 minimum wages (Table 1 ).

It has been found that there was a higher adherence to self-care activities related to taking medication according to the regimen, taking the recommended number of pills for diabetes, ingesting few sweets, and taking insulin injections. The adherence was lower in activities such as testing the blood sugar the adequate number of times, blood sugar testing in the last seven days, carrying out specific exercises, and exercising for at least 30 minutes (Table 2).

Table 1 - Sociodemographic characterization of people with diabetes mellitus type 2, São Luís, Maranhão, Brazil, 2020

\begin{tabular}{|c|c|c|}
\hline Variables & $\mathbf{n}$ & $\%$ \\
\hline \multicolumn{3}{|l|}{ Sex } \\
\hline Female & 188 & 69.6 \\
\hline Male & 82 & 30.4 \\
\hline \multicolumn{3}{|l|}{ Age group (years) } \\
\hline $18-39$ & 5 & 1.9 \\
\hline $40-59$ & 82 & 30.4 \\
\hline $60-69$ & 106 & 39.3 \\
\hline$>70$ & 77 & 28.5 \\
\hline \multicolumn{3}{|l|}{ Marital Status } \\
\hline Married/Stable Union & 127 & 47.0 \\
\hline Single & 79 & 29.3 \\
\hline Widow/widower & 53 & 19.6 \\
\hline Divorced/Separated & 11 & 4.1 \\
\hline \multicolumn{3}{|l|}{ Years of formal education } \\
\hline Illiterate & 25 & 9.3 \\
\hline Elementary school & 156 & 57.8 \\
\hline High School & 77 & 28.5 \\
\hline Higher education & 12 & 4.4 \\
\hline \multicolumn{3}{|l|}{ Profession } \\
\hline Retired & 136 & 50.4 \\
\hline Works at home & 76 & 28.2 \\
\hline Active & 45 & 16.7 \\
\hline Unemployed & 13 & 4.8 \\
\hline \multicolumn{3}{|l|}{ Family income } \\
\hline Less than 1 minimum wage* & 36 & 13.3 \\
\hline From 1 to 2 minimum wages & 217 & 80.4 \\
\hline From 3 to 5 minimum wages & 14 & 5.2 \\
\hline From 6 to 10 minimum wages & 3 & 1.1 \\
\hline
\end{tabular}

Regarding the adherence to the diet (general), it was found a statistically significant association with the age group, with a higher median from 18 to 39 years old, which diminished with age. It also had a relation with $\mathrm{BMI}$ and nutritional follow up (Table 3 ).

In regard to diet (specific) and its items, there was a statistical association between the consumption of fruit and/or vegetables and educational level: the median was higher for those with high school and nutritional follow up, with a positive adherence in those who participated in this follow up. Regarding the eating of sweets, there was a significant relation with family income and $\mathrm{BMI}$, showing that those with higher incomes and lower weight consumed sweets more often (Table 3).

Associating the adherence to exercise and sociodemographic and clinical variables, there was a statistical significance in the age group and in DM complications. Younger people (from 18 to 39) years old and those above 70 years old practice less exercise, and those who exercised more did not show complications in the disease (Table 4).

In regard to blood sugar testing, there was a association with educational level, BMI, medication treatment, DM complications, and medical follow up. Those with higher educational level, who were underweight, who used only insulin, did not show DM complications, and went to medical follow up, adhered more to the glycemic testing.

The item "Check your feet", which belongs to the dimension "Foot care", was only statistically significant for the age group, with a higher median for people from 18 to 39 years. Its adherence diminished with age. Regarding drying between one's toes after washing the feet, only the follow up with nurses had a significant relation with this type of care (Table 5).

Regarding the use of medication, the variables age group, educational level, participating in education groups for diabetes, time of diagnosis, DM complications, and medical and nurse follow up, had no significant association with the adherence to recommended diabetes medication intake (Table 5).

\section{DISCUSSION}

The nutritional approach of people with DM demands changes in lifestyle based on a care focused on the individual and the definition of individual objectives adequate in regard to the cultural and behavioral context, to reach a good adherence to dietary guidance, avoiding or delaying the complications of diabetes ${ }^{(1)}$. Studies carried out in Brazil ${ }^{(10-11)}$ and Nigeria ${ }^{(12)}$ show a high adherence of people with DM to the self-care activities associated with general diet, as opposed to the result found in our study, according to which less than half the interviewees followed a healthy diet and the dietary recommendations from health professionals from 5 to 7 days a week. this can be related to the predominance of a low educational level in the interviewees, reflecting on difficulties in understanding the guidance of professionals.

Still in regards to diet, a stronger adherence was found for specific items, such as the intake of fruit and/or vegetables and low intake of sweets, showing the desirable self-care in regard to specific diet - the same result found in another research in the Brazilian Northwest ${ }^{(11)}$. One reason for this could be in the lower financial cost for the acquisition of natural foods and fin the elementary notion of the need to restrict sweet consumption to better control the disease. 
Table 2 - Distribution of people with diabetes mellitus type 2 according with the adherence to self-care activities to manage the disease, São Luís, Maranhão, Brazil, 2020

\begin{tabular}{|c|c|c|c|}
\hline \multirow[b]{2}{*}{ Self-care activities for diabetes } & \multicolumn{2}{|c|}{ Frequency (No. of days of the week) } & \multirow[b]{2}{*}{ Median $\pm I Q R^{*}$} \\
\hline & $\begin{array}{c}0 \text { to } 4 \text { days } \\
\text { n (\%) }\end{array}$ & $\begin{array}{c}5 \text { to } 7 \text { days } \\
\text { n (\%) }\end{array}$ & \\
\hline \multicolumn{4}{|l|}{ Diet (general) } \\
\hline Followed a healthful eating plan & $137(50.7)$ & $133(49.3)$ & $4.0 \pm 3.0$ \\
\hline Followed your eating plan & $156(57.8)$ & $114(42.2)$ & $4.0 \pm 4.8$ \\
\hline \multicolumn{4}{|l|}{ Diet (specific) } \\
\hline Eat five or more servings of fruit and/or vegetables & $114(42.2)$ & $156(57.8)$ & $5.0 \pm 4.0$ \\
\hline eat high fat foods such as red meat or full-fat dairy products & $202(74.8)^{* *}$ & $68(25.2)^{* *}$ & $1.0 \pm 1.8^{* *}$ \\
\hline meals include sweets & $245(90.7)^{* *}$ & $25(9.3)^{* *}$ & $0.0 \pm 1.0^{* *}$ \\
\hline \multicolumn{4}{|l|}{ Exercise } \\
\hline At least 30 minutes of physical activity & $209(77.4)$ & $61(22.6)$ & $2.0 \pm 4.0$ \\
\hline Participated in a specific exercise session & $222(82.2)$ & $48(17.8)$ & $0.0 \pm 3.0$ \\
\hline \multicolumn{4}{|l|}{ Blood sugar testing } \\
\hline Tested blood sugar & $235(87)$ & $35(13.0)$ & $1.0 \pm 2.0$ \\
\hline Tested blood sugar the number of times recommended by your health care provider & $236(87.4)$ & $34(12.6)$ & $1.0 \pm 2.0$ \\
\hline \multicolumn{4}{|l|}{ Foot care } \\
\hline Checked the feet & $88(32.6)$ & $182(67.4)$ & $5.0 \pm 3.8$ \\
\hline Inspected the inside of shoes & $110(40.7)$ & $160(59.3)$ & $5.0 \pm 3.0$ \\
\hline Dried between toes after washing & $70(25.9)$ & $200(74.1)$ & $6.0 \pm 3.0$ \\
\hline \multicolumn{4}{|l|}{ Medications } \\
\hline Took recommended diabetes medication & $23(8.5)$ & $247(91.5)$ & $7.0 \pm 0.0$ \\
\hline Took recommended insulin injections & $10(15.6)$ & $54(84.4)$ & $7.0 \pm 0.0$ \\
\hline Took recommended number of diabetes pills & $23(9.4)$ & $221(90.6)$ & $7.0 \pm 0.0$ \\
\hline
\end{tabular}

${ }^{*}$ Median and interquartile range; **Results described before the values were inverted.

Table 3 - Association of the sociodemographic and clinical variables of people with diabetes mellitus type 2 with their adherence to self-care activities of diet (general) and diet (specific), São Luís, Maranhão, Brazil, 2020

\begin{tabular}{|c|c|c|c|c|c|c|}
\hline \multirow[t]{2}{*}{ Variables } & \multicolumn{2}{|c|}{ Diet (general) } & \multicolumn{2}{|c|}{$\begin{array}{c}\text { Diet (specific) } \\
\text { (fruits and/or vegetables) }\end{array}$} & \multicolumn{2}{|c|}{$\begin{array}{l}\text { Diet (specific) } \\
\quad \text { (sweets) }\end{array}$} \\
\hline & Median \pm IQR* & $p$ value ${ }^{* *}$ & Median \pm IQR* & $p$ value $* *$ & Median \pm IQR* & $p$ value ${ }^{* *}$ \\
\hline Age group (years) & & 0.018 & & 0.723 & & 0.811 \\
\hline $18-39$ & $7.0 \pm 7.0$ & & $7.0 \pm 6.0$ & & $7.0 \pm 1.0$ & \\
\hline $40-59$ & $4.0 \pm 3.8$ & & $5.0 \pm 4.0$ & & $7.0 \pm 1.0$ & \\
\hline $60-69$ & $5.0 \pm 3.0$ & & $5.0 \pm 4.0$ & & $7.0 \pm 1.0$ & \\
\hline$>70$ & $3.5 \pm 3.0$ & & $5.0 \pm 3.0$ & & $7.0 \pm 1.0$ & \\
\hline Years of formal education & & 0.110 & & 0.015 & & 0.138 \\
\hline Illiterate & $3.5 \pm 4.0$ & & $5.0 \pm 3.0$ & & $7.0 \pm 1.0$ & \\
\hline Elementary school & $4.0 \pm 3.0$ & & $5.0 \pm 3.0$ & & $7.0 \pm 1.0$ & \\
\hline High School & $4.0 \pm 3.0$ & & $5.0 \pm 4.0$ & & $7.0 \pm 1.0$ & \\
\hline Higher education & $5.5 \pm 3.0$ & & $6.0 \pm 1.2$ & & $6.0 \pm 2.0$ & \\
\hline Family income & & 0.926 & & 0.117 & & 0.033 \\
\hline Less than 1 minimum wage & $4.5 \pm 4.0$ & & $5.0 \pm 4.0$ & & $7.0 \pm 0.0$ & \\
\hline From 1 to 2 minimum wages & $4.0 \pm 3.5$ & & $5.0 \pm 3.0$ & & $7.0 \pm 1.0$ & \\
\hline From 3 to 5 minimum wages & $4.0 \pm 3.5$ & & $6.5 \pm 1.8$ & & $6.0 \pm 1.0$ & \\
\hline From 6 to 10 minimum wages & $4.0 \pm 1.8$ & & $4.0 \pm 1.5$ & & $5.0 \pm 3.0$ & \\
\hline Education group for diabetes & & 0.553 & & 0.622 & & 0.074 \\
\hline Yes & $4.0 \pm 3.5$ & & $5.0 \pm 4.0$ & & $7.0 \pm 1.0$ & \\
\hline No & $4.0 \pm 4.0$ & & $5.0 \pm 3.0$ & & $7.0 \pm 1.0$ & \\
\hline Body Mass Index & & 0.035 & & 0.467 & & 0.035 \\
\hline Underweight & $2.0 \pm 0.0$ & & $7.0 \pm 0.0$ & & $5.0 \pm 0.0$ & \\
\hline Normal & $5.0 \pm 4.0$ & & $5.0 \pm 4.0$ & & $7.0 \pm 0.2$ & \\
\hline Overweight & $4.0 \pm 4.0$ & & $5.0 \pm 3.0$ & & $7.0 \pm 1.0$ & \\
\hline Obesity & $3.5 \pm 3.0$ & & $5.0 \pm 3.0$ & & $7.0 \pm 1.0$ & \\
\hline Time of diagnoses & & 0.489 & & 0.157 & & 0.770 \\
\hline Less than 5 years & $4.0 \pm 4.0$ & & $5.0 \pm 3.0$ & & $7.0 \pm 1.0$ & \\
\hline 5 to 10 & $4.0 \pm 3.5$ & & $5.0 \pm 4.0$ & & $7.0 \pm 1.0$ & \\
\hline More than 10 years & $4.0 \pm 3.0$ & & $5.0 \pm 4.0$ & & $7.0 \pm 1.0$ & \\
\hline Nutritional follow up & & 0.000 & & 0.000 & & 0.276 \\
\hline Yes & $5.0 \pm 3.0$ & & $6.0 \pm 3.0$ & & $7.0 \pm 0.5$ & \\
\hline No & $4.0 \pm 3.0$ & & $5.0 \pm 3.0$ & & $7.0 \pm 1.0$ & \\
\hline Follow up with nurse & & 0.705 & & 0.892 & & 0.975 \\
\hline Yes & $4.0 \pm 2.0$ & & $5.0 \pm 3.0$ & & $7.0 \pm 1.0$ & \\
\hline No & $4.0 \pm 4.0$ & & $5.0 \pm 4.0$ & & $7.0 \pm 1.0$ & \\
\hline
\end{tabular}


Table 4 - Association of the sociodemographic and clinical variables of people with diabetes mellitus type 2 with their adherence to self-care activities of exercise and blood sugar testing, São Luís, Maranhão, Brazil, 2020

\begin{tabular}{|c|c|c|c|c|}
\hline \multirow{2}{*}{ Variables } & \multicolumn{2}{|c|}{ Exercise } & \multicolumn{2}{|c|}{ Blood sugar testing } \\
\hline & Median \pm IQR* & $p$ value $* *$ & Median \pm IQR* & $p$ value ${ }^{* *}$ \\
\hline Age group (years) & & 0.007 & & 0.545 \\
\hline $18-39$ & $0.0 \pm 3.5$ & & $1.0 \pm 7.0$ & \\
\hline $40-59$ & $1.5 \pm 3.0$ & & $1.0 \pm 1.0$ & \\
\hline $60-69$ & $2.0 \pm 4.5$ & & $1.0 \pm 2.0$ & \\
\hline$>70$ & $0.0 \pm 2.0$ & & $1.0 \pm 1.0$ & \\
\hline Years of formal education & & 0.354 & & 0.040 \\
\hline Illiterate & $1.0 \pm 5.0$ & & $0.0 \pm 1.0$ & \\
\hline Elementary school & $1.5 \pm 4.0$ & & $1.0 \pm 1.0$ & \\
\hline High School & $1.5 \pm 3.0$ & & $1.0 \pm 2.0$ & \\
\hline Higher education & $1.2 \pm 2.0$ & & $3.5 \pm 6.0$ & \\
\hline Education group for diabetes & & 0.111 & & 0.164 \\
\hline Yes & $2.0 \pm 3.2$ & & $1.0 \pm 2.0$ & \\
\hline No & $1.0 \pm 3.5$ & & $1.0 \pm 1.0$ & \\
\hline Body Mass Index & & 0.086 & & 0.045 \\
\hline Underweight & $1.0 \pm 0.0$ & & $7.0 \pm 0.0$ & \\
\hline Normal & $1.5 \pm 3.5$ & & $1.0 \pm 1.0$ & \\
\hline Overweight & $1.5 \pm 5.0$ & & $1.0 \pm 1.0$ & \\
\hline Obesity & $0.8 \pm 2.6$ & & $1.0 \pm 2.0$ & \\
\hline Time of diagnoses & & 0.149 & & 0.056 \\
\hline Less than 5 years & $1.5 \pm 4.0$ & & $0.5 \pm 1.0$ & \\
\hline 5 to 10 & $2.0 \pm 3.5$ & & $1.0 \pm 2.0$ & \\
\hline More than 10 years & $1.0 \pm 3.0$ & & $1.0 \pm 2.0$ & \\
\hline Medications & & 0.229 & & 0.000 \\
\hline Only oral antidiabetic & $1.5 \pm 3.5$ & & $1.0 \pm 1.0$ & \\
\hline Oral antidiabetic and insulin & $1.0 \pm 3.0$ & & $2.0 \pm 6.5$ & \\
\hline Only insulin & $0.5 \pm 2.5$ & & $5.0 \pm 6.2$ & \\
\hline Diabetes complications & & 0.009 & & 0.045 \\
\hline Yes & $0.8 \pm 3.0$ & & $1.0 \pm 2.0$ & \\
\hline No & $2.0 \pm 4.0$ & & $2.0 \pm 1.0$ & \\
\hline Medical follow up & & 0.101 & & 0.003 \\
\hline Yes & $1.5 \pm 3.5$ & & $1.0 \pm 2.0$ & \\
\hline No & $0.0 \pm 1.2$ & & $0.0 \pm 0.0$ & \\
\hline Follow up with nurse & & 0.413 & & 0.144 \\
\hline Yes & $2.0 \pm 4.0$ & & $1.0 \pm 2.0$ & \\
\hline No & $1.0 \pm 3.5$ & & $1.0 \pm 1.0$ & \\
\hline
\end{tabular}

${ }^{*}$ Median and interquartile range; **Mann-Whitney's and Kruskal-Wallis's tests.

Table 5 - Association of the sociodemographic and clinical variables of people with diabetes mellitus type 2 with their adherence to self-care activities of foot care and medications, São Luís, Maranhão, Brazil, 2020

\begin{tabular}{|c|c|c|c|c|c|c|}
\hline \multirow[t]{2}{*}{ Variables } & \multicolumn{2}{|c|}{$\begin{array}{c}\text { Foot care } \\
\text { (checking the feet) }\end{array}$} & \multicolumn{2}{|c|}{$\begin{array}{c}\text { Foot care } \\
\text { (drying between toes) }\end{array}$} & \multicolumn{2}{|c|}{$\begin{array}{c}\text { Medications } \\
\text { (taking medications) }\end{array}$} \\
\hline & Median $\pm I^{*} R^{*}$ & $p$ value ${ }^{* *}$ & Median $\pm I^{Q} R^{*}$ & $p$ value ${ }^{* *}$ & Median $\pm I Q R^{*}$ & $p$ value ${ }^{* *}$ \\
\hline Age group (years) & & 0.048 & & 0.123 & & 0.930 \\
\hline $18-39$ & $7.0 \pm 1.0$ & & $1.0 \pm 5.0$ & & $7.0 \pm 0.0$ & \\
\hline $40-59$ & $6.0 \pm 3.8$ & & $6.0 \pm 2.0$ & & $7.0 \pm 0.0$ & \\
\hline $60-69$ & $5.0 \pm 2.8$ & & $6.0 \pm 1.0$ & & $7.0 \pm 0.0$ & \\
\hline$>70$ & $5.0 \pm 3.0$ & & $5.0 \pm 2.0$ & & $7.0 \pm 0.0$ & \\
\hline Years of formal education & & 0.070 & & 0.124 & & 0.825 \\
\hline Illiterate & $5.0 \pm 5.0$ & & $5.0 \pm 3.0$ & & $7.0 \pm 0.0$ & \\
\hline Elementary school & $5.0 \pm 2.2$ & & $6.0 \pm 1.0$ & & $7.0 \pm 0.0$ & \\
\hline High School & $6.0 \pm 3.0$ & & $6.0 \pm 2.0$ & & $7.0 \pm 0.0$ & \\
\hline Higher education & $5.5 \pm 4.8$ & & $5.5 \pm 6.2$ & & $7.0 \pm 0.0$ & \\
\hline Education group for diabetes & & 0.078 & & 0.288 & & 0.235 \\
\hline Yes & $6.0 \pm 2.0$ & & $6.0 \pm 2.0$ & & $7.0 \pm 0.0$ & \\
\hline No & $5.0 \pm 4.0$ & & $5.0 \pm 3.0$ & & $7.0 \pm 0.0$ & \\
\hline Time of diagnoses & & 0.151 & & 0.605 & & 0.110 \\
\hline Less than 5 years & $5.0 \pm 3.0$ & & $5.0 \pm 2.0$ & & $7.0 \pm 0.0$ & \\
\hline 5 to 10 & $6.0 \pm 2.0$ & & $6.0 \pm 3.0$ & & $7.0 \pm 0.0$ & \\
\hline More than 10 years & $5.0 \pm 4.0$ & & $5.0 \pm 2.8$ & & $7.0 \pm 0.0$ & \\
\hline Diabetes complications & & 0.772 & & 0.967 & & 0.668 \\
\hline Yes & $5.0 \pm 4.0$ & & $5.0 \pm 3.0$ & & $7.0 \pm 0.0$ & \\
\hline No & $5.0 \pm 2.0$ & & $6.0 \pm 1.0$ & & $7.0 \pm 0.0$ & \\
\hline
\end{tabular}




\begin{tabular}{|c|c|c|c|c|c|c|}
\hline \multirow[t]{2}{*}{ Variables } & \multicolumn{2}{|c|}{$\begin{array}{c}\text { Foot care } \\
\text { (checking the feet) }\end{array}$} & \multicolumn{2}{|c|}{$\begin{array}{c}\text { Foot care } \\
\text { (drying between toes) }\end{array}$} & \multicolumn{2}{|c|}{$\begin{array}{c}\text { Medications } \\
\text { (taking medications) }\end{array}$} \\
\hline & Median \pm IQR* & $p$ value $^{* *}$ & Median \pm IQR* & $p$ value ${ }^{* *}$ & Median \pm IQR* & $p$ value ${ }^{* *}$ \\
\hline Medical follow up & & 0.817 & & 0.675 & & 0.098 \\
\hline Yes & $5.0 \pm 3.0$ & & $6.0 \pm 2.0$ & & $7.0 \pm 0.0$ & \\
\hline No & $5.0 \pm 4.0$ & & $5.0 \pm 5.5$ & & $7.0 \pm 0.5$ & \\
\hline Follow up with nurse & & 0.088 & & 0.012 & & 0.124 \\
\hline Yes & $5.0 \pm 3.0$ & & $5.0 \pm 2.0$ & & $7.0 \pm 0.0$ & \\
\hline No & $5.0 \pm 3.0$ & & $6.0 \pm 2.0$ & & $7.0 \pm 0.0$ & \\
\hline
\end{tabular}

*Median and interquartile range; **Mann-Whitney's and Kruskal-Wallis's tests.

Considering that a significant part of the interviewees were elders and had complications due to the diabetes, the practice of exercise was one of the self-care activities with low adherence, due to possible physical limitations and lack of motivation. however, many strategies that elevate self-efficacy and motivation can be employed to increase the adherence and continuity of exercises, such as defining specific goals, using self-monitoring tools, developing a plan to overcome obstacles and supervised exercise programs, contributing for a better glycemic control and to manage long-term weight loss ${ }^{(13)}$.

Monitoring the blood sugar also had a low adherence, a result similar to that of other researches ${ }^{(14-15)}$ about the topic. The scientific literature ${ }^{(1)}$ recommends that capillary glycemia self-monitoring should only be practices routinely by those who use insulin, with no consensus in regard to those who only use oral antidiabetic drugs. Therefore, following this recommendation may be influencing the low adherence to blood sugar monitoring, since most users only use oral antidiabetic drugs.

In regard to foot care, there was a favorable adherence, since most interviewees examined their feet and dried the space between the toes after washing them. This type of care is important to identify early potential changes in the feet and prevent complications ${ }^{(10)}$. Diabetic foot injuries are one of the most common complications of the disease, and $20 \%$ of people with DM are at risk of foot ulcers as a result of the neuropathy. Therefore, good knowledge and practices regarding the prevention of diabetic foot injuries reduce the risk of complications, including the amputation of lower limbs ${ }^{(16)}$.

In regard to the use of medications, the adherence was greater in regard to following recommendations for medication intake, insulin injections, and for the recommended number of diabetes pills. This shows the importance that these people give to medication treatment, probably due to potential influences from the hospital-focused model. It is remarkable that another research ${ }^{(17)}$ carried out in the state of Paraíba, showed a similar result, despite involving a different socioeconomic reality, considering that the adherence could be affected by different traditions, costumes, and environmental factors between societies and regions ${ }^{(18)}$.

Regarding the adherence to the diet in general, those from 18 to 39 years of age were the ones who adhered the most to a healthy diet and to the guidance given by a health professional. This result can be justified due to the fact that these are younger people, who are more worried about controlling the disease and its complications. As opposed to our findings, another research ${ }^{(10)}$ did not find a statistical association between general diet and age. People with normal weight, who had nutritional follow ups, also adhered more to this self-car activity: they showed commitment in following the recommendations from health workers through healthy diets, thus reiterating the importance of the actions of the nutritionist.

Among the variables with no statistical associations, such as general diet, educational level, family income, participation in educational groups in diabetes, and time of diagnosis. That is, neither those with higher educational and financial levels, which, a priori, would be able to purchase healthier foods, nor those who participated in the diabetes education group or had the disease for longer, had good results in this dimension of self-care. This finding is worrisome, showing how often those with DM are subjected to the complications of this silent disease, which may even result in high costs for the public health services.

Similarly, a research carried out in the hinterland of São Paulo(10) did not find statistically significance between general diet and educational level or time of diagnosis, although it found an association with income, according to which those with worse financial conditions adhered more to the general diet. This finding, therefore, goes against the understanding that those with better incomes are more likely to acquire and follow dietary recommendations.

Regarding specific diet, a significant relation was found between the intake of fruit and/or vegetables and the educational level and nutritional follow up, showing that the actions from public managers to broaden and improve education in Brazil are indispensable, including a valorization of health professionals, especially of the activity of nutritionists. In regard to intake of sweets, it had a relation with the income and the BMI, where those with a higher income consumed more sweets. In this regard, people with diabetes have trouble accepting and implementing changes in the dietary habits as recommended by nutritionists ${ }^{(1)}$.

Regarding the adherence to exercise, there was a statistically significant association with the age group and DM complications, which can be explained by the fact that people from 60 to 69 years old, with no complications of the disease, are more committed to practicing exercise to improve their health and quality of life. A research ${ }^{(19)}$ with similar results, carried out in the state of Rio Grande do Sul, suggests associations with age, reiterating the interventions to encourage behavioral changes in inactive older adults with DM should be studied and used to promote regular exercise, seeking satisfactory results for the control and treatment of the disease.

The adherence to blood sugar monitoring showed a statistically significant relation with educational level, $\mathrm{BMI}$, medications, complications of the DM, and medical follow up. However, in a 
research carried out in the state of São Paulo, the same relation with educational level and $\mathrm{BMI}^{(10)}$ could not be observed. This contradiction of results may happen due to the regional differences relative to the socioeconomic development.

Those who used, exclusively, insulin, or even associated it with oral antidiabetics and medical follow up, adhered better to the monitoring of glycemia, following the recommendations for a better control of glycemia and adjusts in eating and taking medication as needed. Therefore, measuring the capillary glycemia has become an essential tool that allows people with diabetes to take immediate action, guaranteeing a better follow up and treatment ${ }^{(1)}$.

Regarding foot care, there was a statistical association of foot exams and age group - a similar result to that of a study ${ }^{(10)}$ car- $^{-}$ ried out in the state of São Paulo. Regarding the drying of spaces between the toes after washing them, it only had a significant association with nurse follow up, showing the importance of this health worker for the adherence to this type of care. Similarly, a research ${ }^{(20)}$ carried out in the Teresina, in the state of Piaui (PI),indicated a significant relation between the guidance made available by nurses to those with diabetes and the adherence to the activity of foot care. Therefore, the essence for the adherence to self-care, and, therefore, for the prevention against changes in the feet of those with diabetes, is correlated with the knowledge about the disease ${ }^{(21)}$. As a result, the positive repercussions of the follow up of this professional in the self-care of people with diabetes are reiterated, considering the benefits of sharing educational guidance.

There was no statistical relation between the taking of medications and the variables tested in this research. As opposed to these findings, studies from Africa and Saudi Arabia ${ }^{(22-23)}$ found an association with the variables Age and Educational level, according to which younger people and those with low educational levels adhered the least to this activity. These results highlight the importance of a health education adapted to the needs of the patient, going beyond raising the awareness of the individual about the adherence to the medication treatment to control the diabetes.

Furthermore, it was found that the participation in education groups in diabetes and the time since the diagnosis of the disease had no association with the adherence to self-care activities. However, follow up with the nurse had an association with an activity in the dimension Foot care: the item Drying between toes. After all, a consensus that being involved in educational groups in diabetes and the knowledge acquired throughout the treatment of the disease, in addition to actions of the nurse focused on self-care, have a positive impact on the control of the disease.

Therefore, the adherence to the self-care activities has a direct relation with the control of the disease, and, as a result, to the wellbeing of people with DM2. this, it is important to implement individual and collective actions to promote health and prevent complications, to encourage behavior targeted at health and reflect on an improvement in the quality of life of people with diabetes ${ }^{(12,24-25)}$.

\section{Study limitations}

The limitations of this study are related with the fact that the data was self-reported by the participants, and it was not possible to verify some of their clinical parameters, such as blood sugar and glycated hemoglobin. However, these limitations did not prevent us from reaching the goals of this work, considering the use of a structured instrument that was applied by aptly trained researchers. Additionally, the absence of the clinical parameters mentioned did not impair the validity of the results, only impacting them from the perspective of the types of clinical data studied.

\section{Contributions to the Field of Nursing}

The adherence to self-care activities in the treatment of diabetes has shown itself to be a daily challenge for the health team, especially for the nursing team. The relevance of the associations between the adherence to self-care and the sociodemographic and clinical variables, found in this study, should especially be highlighted. These results guide the adoption of strategies and interventions targeted at people with diabetes, since, in clinical practice, it is essential for the nurse to implement educational, behavioral, and motivational actions, targeted at people with DM2 and their families, valuing their individuality from the perspective of improving their adherence to selfcare actions.

\section{CONCLUSIONS}

This study found that there are factors related to the adherence of self-care activities in people with diabetes. This finding makes it possible to strengthen the line of care of chronic diseases, reiterating how important it is for health workers to give an assertive direction to educational actions, leading to a positive adherence to self-care and, thus, contributing in the prevention of complications and improving the quality of life of those with diabetes.

\section{REFERENCES}

1. Sociedade Brasileira de Diabetes - SBD. Diretrizes da Sociedade Brasileira de Diabetes [Internet]. 2019-2020; [cited 2019 Dec 18]. Available from: https://www.diabetes.org.br/profissionais/images/DIRETRIZES-COMPLETA-2019-2020.pdf

2. International Diabetes Federation. IDF diabetes atlas[Internet]. 9th. ed. International Diabetes Federation; 2019. [cited 2019 Nov 20]. Available from: http://www.diabetesatlas.org/

3. American Diabetes Association. Standards of Medical Care in Diabetes. Diabetes Care [Internet]. 2021 [cited 2021 Jul 24];44(Suppl 1):S1S207. Available from: https://care.diabetesjournals.org/content/44/Supplement_1

4. Dyonisio G, Vicente NG, Assunção LM, Molina NPFM, Rodrigues LR. Factors related to self-care activities adherence of older adults with diabetes. Biosci J. 2020;36(2):636-651. https://doi.org/10.14393/BJ-v36n2a2020-42430 
Diabetes mellitus type 2: factors related to adherence to self-care

5. Rocha RB, Silva CS, Cardoso VS. Self-Care in Adults with Type 2 Diabetes Mellitus: A Systematic Review. Curr Diabetes Rev. 2020;16(6):598607. https://doi.org/10.2174/1573399815666190702161849

6. Jardim RMFVS, Leal MCC, Marques APO, Barbosa LS, Cavalcanti MCF, Gomes FMA. Factors associated with the practice of physical activity in older diabetic primary care patients. Geriatr Gerontol Aging. 2020;14:61-70. https://doi.org/10.5327/Z2447-212320201900057

7. Ministério da Saúde (BR). Resolução n 466/12, de 12 de dezembro de 2012. Dispõe sobre pesquisa envolvendo seres humanos [Internet]. Brasília: Ministério da Saúde; 2012 [cited 2019 Apr 10]. Available from: http://bvsms.saude.gov.br/bvs/saudelegis/cns/2013/ res0466_12_12_2012.html

8. Michels MJ, Coral MHC, Sakae TM, Damas TB, Furlanetto LM. Questionário de Atividades de Autocuidado com o Diabetes: tradução, adaptação e avaliação das propriedades psicométricas. Arq Bras Endocrinol Metab. 2010;54(7):644-51. https://doi.org/10.1590/ S0004-27302010000700009

9. Toobert DJ, Hampson SE, Glasgow RE. The summary of diabetes self-care activities measure: results from 7 studies and a revised scale. Diabetes Care. 2000;23(7):943-50. https://doi.org/10.2337/diacare.23.7.943

10. Eid LP, Leopoldino SAD, Oller GASAO, Pompeo DA, Martins MA, Gueroni LPB. Fatores relacionados às atividades de autocuidado de pacientes com diabetes mellitus tipo 2. Esc Anna Nery. 2018;22(4). https://doi.org/10.1590/2177-9465-EAN-2018-0046

11. Larré MC, Otero LM, Teixeira, CRS, Zanetti ML, Inagaki ADM, Abud ACF. Autocuidado dos pacientes com diabetes mellitus tipo 2 em seguimento ambulatorial. Nursing [Internet]. 2018 [cited 2019 Sep 17];21(245):2385-2390. Available from: http://www.revistanursing.com. br/revistas/245/pg23.pdf

12. Jackson IL, Onung SI, Oiwoh EP. Self-care activities, glycaemic control and health-related quality of life of patients with type 2 diabetes in a tertiary hospital in Nigeria. Diabetes Metab Syndr. 2021;15(1):137-143. https://doi.org/10.1016/j.dsx.2020.12.027

13. Sigal RJ, Armstrong MJ, Bacon SL, Boulé NG, Dasgupta K, Kenny GP, et al. Clinical Practice Guidelines. Physical Activity and Diabetes. Can J Diabetes. 2018;42:S54-S63. https://doi.org/10.1016/j.jcjd.2017.10.008

14. Santos EMS, Souza VP, Correio IAG, Correio EBS. Autocuidado de Usuários com Diabetes Mellitus: Perfil Sociodemográfico, Clínico e Terapêutico. Rev Pesqui Cuid Fundam. 2018;10(3):720-8. https://doi.org/10.9789/2175-5361.2018.v10i3.720-728

15. Suplici SER, Meirelles BHS, Lacerda JT, Silva DMGV. Self-care among people with Diabetes Mellitus and quality of care in Primary Health Care. Rev Bras Enferm. 2021;74(2):e20200351. https://doi.org/10.1590/0034-7167-2020-0351

16. Pourkazemi A, Ghanbari A, Khojamli M, Balo H, Hemmati H, Jafaryparvar Z, et al. Diabetic foot care: knowledge and practice. BMC Endocrine Disorders. 2020;20(40):01-08. https://doi.org/10.1186/s12902-020-0512-y

17. Vicente MC, Silva CRR, Pimenta CJL, Bezerra TA, Lucena HKV, Valdevino SC, et al. Capacity and self-care in older adults with diabetes mellitus. Aquichan. 2020;20(3). https://doi.org/10.5294/aqui.2020.20.3.2

18. Alshehri KA, Altuwaylie TM, Alqhtani A, Albawab AA, Almalki AH. Type 2 Diabetic Patients Adherence Towards Their Medications. Cureus. 2020;12(2). https://doi.org/10.7759/cureus.6932

19. Lima AP, Benedetti TRB, Oliveira LZ, Bavaresco SS, Rech CR. Physical activity is associated with knowledge and attitudes to diabetes type 2 in elderly. J Phys Educ [Internet]. 2019;30:e3017. https://doi.org/10.4025/jphyseduc.v30i1.3017

20. Rezende Neta DS, Silva ARV, Silva GRF. Adherence to foot self-care in diabetes mellitus patients. Rev Bras Enferm [Internet]. 2015;68(1):111-6. https://doi.org/10.1590/0034-7167.2015680115p

21. Batista IB, Pascoal LM, Gontijo PVC, Brito PS, Sousa MA, Santos Neto M, et al. Association between knowledge and adherence to foot selfcare practices performed by diabetics. Rev Bras Enferm [Internet]. 2020;73(5). https://doi.org/10.1590/0034-7167-2019-0430

22. Afaya RA, Bam V, Azongo TB, Afaya A, Kusi-Amponsah A, Ajusiyine JM, et al. Medication adherence and self-care behaviours among patients with type 2 diabetes mellitus in Ghana. Plos One. 2020;15(8):e0237710. https://doi.org/10.1371/journal.pone.0237710

23. AlShayban DM, Naqvi AA, Alhumaid O, AlQahtani AS, Islam MA, Ghori SA, et al. Association of Disease Knowledge and Medication Adherence Among Out-Patients With Type 2 Diabetes Mellitus in Khobar, Saudi Arabia. Front Pharmacol. 2020;11:60. https://doi. org/10.3389/fphar.2020.00060

24. Santos AL, Marcon SS, Teston EF, Back IR, Lino IGT, Batista VC, et al. Adherence to the treatment of diabetes mellitus and relationship with assistance in primary care. REME Rev Min Enferm. 2020;24:e-1279. https://doi.org/10.5935/1415-2762.20200008

25. Çalli D, Kartal A. The relationship between self-efficacy of diabetes management and well-being in patients with type 2 diabetes. Niger J Clin Pract 2021;24:393-9. https://doi.org/10.4103/njcp.njcp_280_18 